\title{
МАТЕМАТИЧНЕ МОДЕЛЮВАННЯ ФОРМУВАННЯ ПІСКОВОГО ТІЛА У МІЖВИТКОВОМУ ПРОСТОРІ МЕХАНІЧНОГО СПІРАЛЬНОГО КЛАСИФІКАТОРА
}

Mathematic modeling of formation sand body in mechanical space spiral classifier

\author{
Мацуй А.M. ${ }^{1}$ (Matsuy A.M.) \\ ${ }^{1}$ ORCID: 0000-0001-5544-0175 \\ ${ }^{1}$ Кіровоградський національний технічний університет, Кіровоград, E-mail: Matsuyan@mail.ru \\ Copyright (C) 2014 by author and the journal “Automation technological and business - processes". \\ This work is licensed under the Creative Commons Attribution International License (CC BY). \\ http://creativecommons.org/licenses/by/4.0/
}

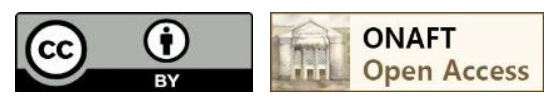

DOI: $10.15673 /$

\begin{abstract}
Анотація
У статті розглядаються питання визначення продуктивності механічного спірального класифікатора по пісках. Подано огляд сучасних досягнень у відповідній області. Поставлена мета роботи - знайти аналітичну залежність об'сму твердого у міжвитковому просторі від його рівня. Для досягнення поставленої мети необхідно було розробити статичну модель піскового тіла спірального класифікатора, яка подана його нижньою і верхньою частинами. Модель нижньої частини подана відрізком циліндра, а верхньої частини зрізаною пірамідою. При такому поданні піскового тіла спірального класифікатора нижня частина описується нелінійною, а верхня частина - лінійною залежністю. Оскільки малі циркулюючі навантаження на практиці не використовуються, в робочому діапазоні зміни витрати пісків класифікатора встановлена практично лінійна залежність об'єму пісків у міжвитковому просторі спіралі від їх рівня. Зважаючи на те, що в процесі математичного моделювання застосовувалися точні аналітичні методи дослідження, отримані результати є об’єктивними. Зроблені допущення щодо подання верхньої частини піскового тіла класифікатора у вигляді зрізаної піраміди не спотворюють процес його формування, оскільки точки, отримані відповідно точному геометричному тілу - відрізку циліндра, знаходяться на загальній залежності, що відповідає і геометричному тілу зі зробленими допущеннями. Тому стверджуємо, що об'єм піскового тіла механічного спірального класифікатора у міжвитковому просторі спіралі можливо визначати за рівнем твердого вздовж вертикалі, яка проходить через точку контакту постелі і заднього витка у самій нижній точці. На основі аналізу результатів моделювання зроблено висновок про можливість прямого вимірювання продуктивності механічного спірального класифікатора по піскам без запізнювання та 3 високою точністю, що відкриває перспективу ефективного керування процесом розділення подрібненої руди за крупністю.
\end{abstract}

\section{Abstract}

The article deals with the determination of mechanical spiral classifier performance on the sand. The review of modern achievements in the relevant field is given. The aim of the work - is to find analytical dependence between solid volume in space interturn and its level. To achieve this aim it was necessary to make a static model of the spiral classifier sand body which submitted its lower and upper parts. Model of the filed bottom is given as the cylinder segment, and top - truncated pyramids. In this representation of the sand body spiral classifier the bottom part describes the non-linear, and the upper part - linear dependence. So as low circulating loads in practice is not used, changes in operating costs range sand classifier established almost linear dependence of the volume of sand in has 
interturn space spiral space of their level. Considering the fact that in the process of mathematical modeling applied precise analytical methods, the results are objective. Assumptions made for the submission of the top of the sand classifier body in the form of truncated pyramids do not distort the process of its formation, as point received under the strict geometric body - segment cylinder are generally depends, corresponding with the body and geometric assumptions made. Therefore, we claim that the volume of sand body mechanical spiral classifier in interturn spiral space is possible to determine by the level of solid along the vertical passing through the point of contact bed and rear coil at the lowest point. Based on the analysis of simulation results concluded that the ability to directly measure the performance of mechanical spiral classifier on the sand without delay and with high precision, opens the prospect of effectively managing the process of separation of crushed ore particle size.

Ключові слова

Класифікатор, спіраль, піски, піскове тіло, продуктивність, об'єм, рівень

Keywords

Classifier, spiral, sands, sand body, performance, volume level

\section{Вступ}

Магнетитовий концентрат як продукт збагачення бідних залізних руд є основою сировини чорної металургії України, однак відрізняється підвищеною собівартістю в наслідок значних перевитрат електроенергії і матеріалів у перших стадіях подрібнення-класифікації. Тому зменшення енергоємності процесів подрібнення і класифікації, яка в перших стадіях здійснюється у механічних спіральних класифікаторах, слід розглядати як найбільш важливу складову на шляху інтенсифікації процесів рудо підготовки. Важливим напрямом зменшення енерго- i матеріаловитрат є удосконалення автоматичного керування процесами розділення руди за крупністю у механічних спіральних класифікаторах, який реалізується у відповідністю з Галузевою програмою енергоефективності та енергозбереження на період до 2017 р., затвердженою наказом Міністра промислової політики України №152 від 25.02.2009 року в частині гірничо-металургійного комплексу та планом наукових досліджень Кіровоградського національного технічного університету. Оскільки дана публікація спрямована на знаходження одного з основних технологічних параметрів механічного спірального класифікатора - його продуктивності по піскам, іï тема $\epsilon$ актуальною.

Огляд сучасного стану розв'язання проблеми

Існують різноманітні підходи щодо визначення продуктивності механічного спірального класифікатора по піскам. Спочатку розроблялись пристрої вимірювання циркулюючого навантаження в замкненому циклі подрібнення класифікації, які мають різні вади і не отримали розповсюдження в збагачувальній галузі. Найбільш ефективним можливо визнати спосіб неперервного вимірювання циркулюючого навантаження розглянутий в роботі [1], однак i тут $є$ суттєвий недолік, оскільки сучасне керування потребує миттєвого реагування на зміни продуктивності по піскам, а він володіє певним відставанням у часі. Згодом були запропоновані способи визначення продуктивності механічного спірального класифікатора по піскам, які отримують подальше удосконалення [2, 3, 4], і зводяться до обчислення продуктивності за формулами 3 використанням великої кількості конструктивних і технологічних параметрів. Перевагою даних способів визначення продуктивності по піскам є номінальна відсутність запізнювання, оскільки передбачається оцінка продукту в межах спіралі класифікатора. Однак недоліком є велика кількість параметрів, які враховуються, і необхідний час їх введення і обчислення, що фактично створює запізнювання. Це привело до розробки способу, де здійснюють вимірювання динамічної складової повного механічного моменту на валу приводного двигуна, який обертає спіраль класифікатора, з виділенням коливання динамічної складової і вимірюванням амплітуди виділених коливань [5]. Удосконалений спосіб визначення продуктивності механічного спірального класифікатора по піскам полягає в оцінці параметра за частотними характеристиками коливань вала спіралі під дією порцій пісків [6]. Його вадою є порівняно низька точність вимірювання параметра в наслідок зміни впливу стану постелі класифікатора, спіралі і механічних вузлів приводу. Тому необхідно розробити підхід вимірювання продуктивності механічного спірального класифікатора, який би реагував на мінімальну кількість матеріалу в спіралі і не відрізнявся б запізнюванням. Він зводиться до математичного моделювання формування піскового тіла у міжвитковому просторі механічного спірального класифікатора.

Мета досліджень 
В процесі математичного моделювання формування піскового тіла механічного спірального класифікатора знайти аналітичну залежність об'єму твердого у міжвитковому просторі від його рівня у визначеній точці і на цій основі зробити висновок про можливість прямого вимірювання продуктивності технологічного агрегату по піскам.

Виклад основного матеріалу

У механічних спіральних класифікаторах спіралі виконують двозахідними, їх розміщують паралельно днищу технологічного агрегату, яке встановлюють під невеликим кутом $\alpha$ до горизонту. Піскове тіло розташовується в просторі між двома елементами сусідніх витків спіралі і постіллю, яка створена 3 рудного продукту і має циліндричну форму. Нехтуючи кривизною спіралі і нахилом іï робочих елементів до циліндричної поверхніпостелі, зобразимо піскове тіло між витками, яке відповідає найбільшому значенню об'єму матеріалу, у горизонтальній площині (рис.1). При цьому рахуємо, що витки спіралі знаходяться у площині, розташованій під кутом $\gamma$ до їх осі, яка в перетині з площиною, що проходить через вісь і паралельна днищу класифікатора, створює пряму $A B$ (рис.1). Дана пряма є гіпотенузою прямокутного трикутника $A B C, 3$ якого

$$
\gamma=\operatorname{arctg} \frac{4 R_{c}}{B_{c}},(1)
$$

де $R_{c}, B_{c}$ - відповідно радіус і крок спіралі, оскільки $B C=2 R_{c}, A C=B_{c} / 2$. Пряма $D E$, яка є частиною прямої $A C$, належить плоскій геометричній фігурі $D^{\prime} E^{\prime} E D$, що складає найбільшу площу горизонтальної поверхні піскового тіла. У геометричній фігурі $D^{\prime} E^{\prime} E D$ основи $D^{\prime} E^{\prime}$ і $D E \epsilon$ прямими, а $D^{\prime} D$ і $E^{\prime} E-$ криві, зважаючи на те, що горизонтальна площина, яка утворює $D^{\prime} E{ }^{\prime} E D$, перетинає циліндричну поверхню розташовану під кутом. Зважаючи на те, що кривизна тут незначна, можливо рахувати $D^{\prime} D$ і $E^{\prime} E$ прямими лініями, а фігуру $D^{\prime} E{ }^{\prime} E D-$ трапецією. Площа трапеції $D^{\prime} E^{\prime} E D$ відповідає найвищому значенню рівня пісків між витками спіралі. При пониженні рівня пісків площа трапеції буде зменшуватись до певного граничного значення.

У вертикальній площині піскове тіло між витками спіралі можливо охарактеризувати його розрізом по осі обертання спіралі, що показано на рис.2. 3 рис.2 слідує, що піскове тіло механічного спірального класифікатора складається з двох частин 3 і 6 . Нижня частина піскового тіла 6 являє собою відрізок циліндра [7] діаметром 2R $R_{c}$ Відрізок циліндра має горизонтальну площину, що проходить від основи переднього витка спіралі 4 через точку, віддалену від основи заднього витка спіралі 5 на відрізок $h_{c}$. Відрізок $h_{c}$ має довжину

$$
h_{c}=\frac{B_{c}}{2} \sin \alpha
$$

і є константою для конкретного механічного спірального класифікатора.

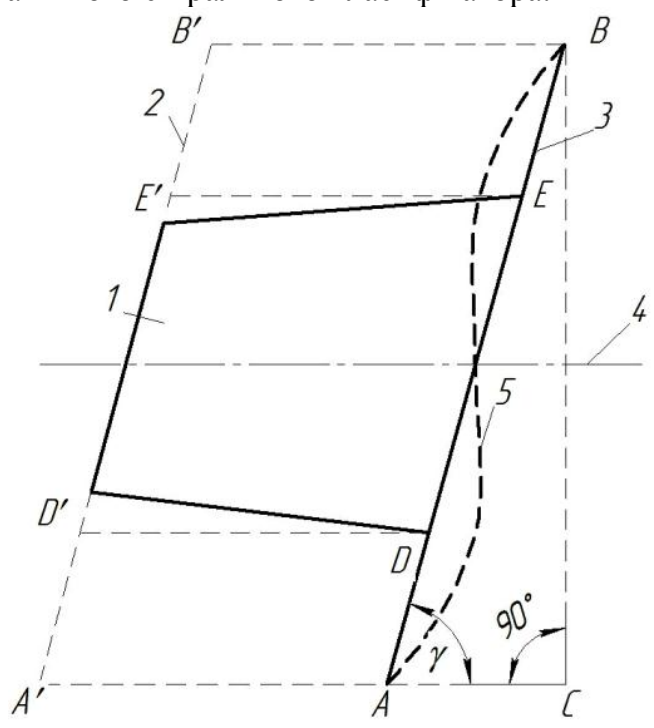

1 - горизонтальна поверхня піскового тіла; 2, 3 - відповідно проекиія переднього $і$ заднього витків спіралі в напрямку руху пісків; 4 - проекція осі обертання на постіль класифікатора; 5 - проекція піввитка спіралі на площину, паралельну днищу класифікатора

Рис.1 - Вид піскового тіла між витками у горизонтальній площині при найбільшому значенні рівня пісків 
Верхня частина піскового тіла 3 розташована над нижнім пісковим тілом 6. Вона являє собою об'ємну фігуру складної форми, яка розповсюджується до верхньої відмітки робочого елемента заднього витка спіралі висотою $h_{e}$.

В процесі експлуатації рівень пісків $h$ від найменшого початкового значення може збільшуватись до найбільшого значення $h_{e}$. Рівень пісків між витками спіралі класифікатора можливо визначати в частках висоти робочого елемента $h_{e}$ або вздовж вертикалі як це показано на рис.2. Найбільше значення рівня пісків у вертикальній площині дорівнює

$$
h_{\max }=h_{e} \cos \alpha .
$$

Величина $h_{\max }$ також $є$ константою для конкретного механічного спірального класифікатора.

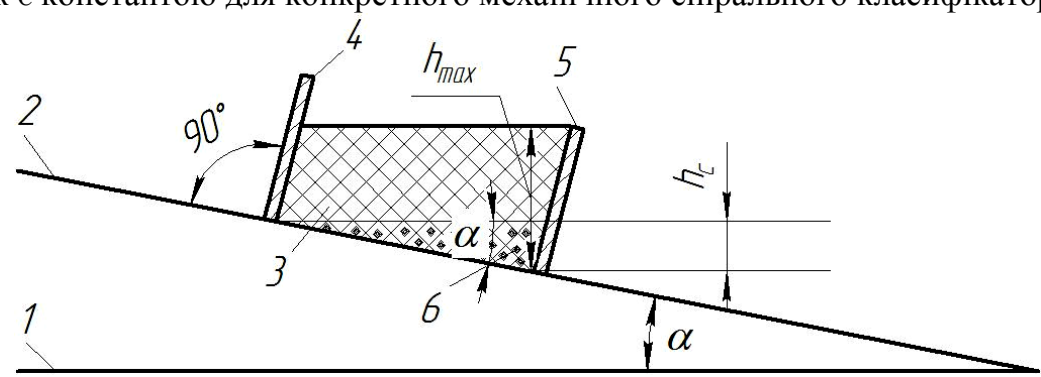

1 - горизонталь; 2 -днище класифікатора, постіль; 3 - верхня частина піскового тіла; 4 , 5 - відповідно передній $i$ задній виток спіралі; 6 - нижня частина піскового тіла; $\alpha$ - кут нахилу класифікатора до горизонталі

Рис. 2 - Розріз піскового тіла між витками спіралі у вертикальній площині, що проходить через вісь обертання, при найбільшому значенні рівня матеріалу

Відрізок циліндра, що характеризує нижню частину піскового тіла, має вигляд, який показано на рис.3. Тут же приведені його параметри. Для визначення об’єму відрізка циліндра з певними параметрами (рис.3) запропонована в [7] залежність

$$
V_{B C}=\frac{l}{3 h_{e a}}\left[a\left(3 R_{c}^{2}-a^{2}\right)+3 R_{c}^{2}\left(h_{e a}-R_{c}\right) \beta\right]=\frac{l R_{c}^{3}}{h_{e a}}\left(\sin \beta-\frac{\sin ^{3} \beta}{3}-\beta \cos \beta\right),
$$

де $\beta=\varphi / 2$.

Залежність (4) призначена для визначення об'єму відрізка циліндра з незмінними параметрами. У випадку формування піскового тіла механічного спірального класифікатора рівень пісків $h_{e a}$ змінюється, однак $(4)$ при $h_{e a}=0$ перетворює об’єм у нескінченість, що не дозволяє застосовувати дану залежність. Тому удосконалимо їі.

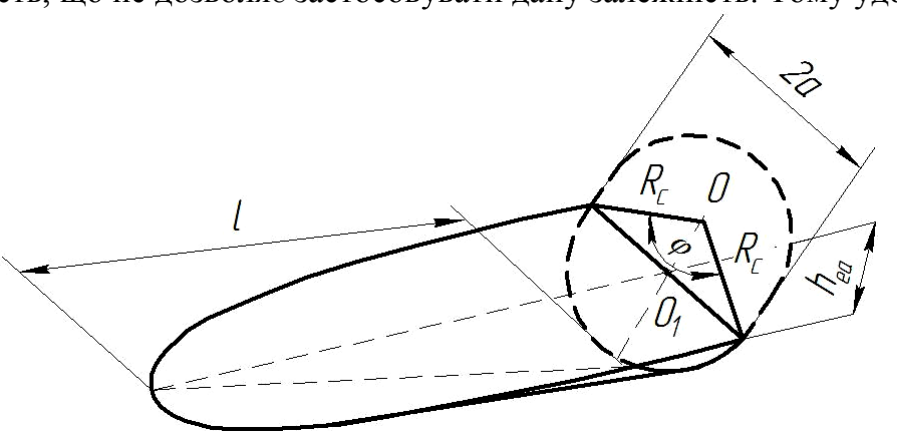

Рис.3 - Відрізок циліндра, що характеризує нижню частину піскового тіла механічного спірального класифікатора

Одним 3 напрямів удосконалення (4) $є$ використання зв'язку $l$ i $h_{e a}$ при зміні рівня пісків, іншим знаходження зв'язку кута $\beta$ і рівня пісків $h_{e a}$. 3 рис. 2 видно, що висоту відрізка циліндра можливо визначити за залежністю

$$
l=h_{e a} / \operatorname{tg} \alpha,
$$

де $h_{e a}$ - розмір відрізка циліндра (матеріалу) вздовж висоти робочого елемента спіралі.

3 врахуванням (5) залежність (4) подамо у вигляді

$$
V_{B C}=\frac{R_{c}^{3}}{\operatorname{tg} \alpha}\left(\sin \beta-\frac{\sin ^{3} \beta}{3}-\beta_{p} \cos \beta\right),
$$


де $\beta_{p}-$ кут $\beta$ в радіанах.

3 рис. 3 визначимо $O O_{1}$ як $O O_{1}=R_{c}-h_{e a}$. Тоді, приймаючи $\beta=\varphi / 2$,

$$
\cos \beta=\frac{O O_{1}}{R_{c}}=\left(R_{c}-h_{e a}\right) / R_{c}=1-h_{e a} / R_{c},
$$

звідки

$$
\beta=\arccos \left(1-h_{e a} / R_{c}\right)=\arccos \left(1-h / R_{c} \cos \alpha\right),
$$

враховуючи, що $h_{e a}=h / \cos \alpha$.

3 врахуванням (8) залежність (6) подамо у вигляді

$$
V_{B C}=\frac{R_{c}^{3}}{\operatorname{tg} \alpha}\left[\sin \arccos \left(1-h / R_{c} \cos \alpha\right)-\frac{\sin ^{3} \arccos \left(1-h / R_{c} \cos \alpha\right)}{3}-\beta_{p} \cos \arccos \left(1-h / R_{c} \cos \alpha\right)\right] .
$$

3 залежності (9) витікає, що об’єм частини піскового тіла механічного спірального класифікатора, яка має форму відрізка циліндра, при певних $\alpha$ і $R_{c}$ однозначно визначається рівнем пісків $h$ у міжвитковому просторі спіралі. Значення рівня $h$ в (9) може змінюватись в межах $0 \ldots h_{c}$.

Верхня частина піскового тіла механічного спірального класифікатора у горизонтальних перерізах містить трапеції аналогічно фігурі $D^{\prime} E$ ' $E D$ на рис.1. Бічні сторони цих трапецій зливаються з циліндричною поверхнею. Зважаючи на те, що діаметр циліндра великий, а рівень пісків порівняно з ним незначний, можливо знехтувати кривизною і вважати, що бічні грані верхньої частини піскового тіла являють собою площини. Тоді верхню частину піскового тіла класифікатора можливо подати у вигляді, зображеному на рис.4. Наближено ï можна розглядати як зрізану піраміду з основами $E_{c}^{\prime} E^{\prime} D^{\prime} D_{c}^{\prime}, E_{c} E D D_{c}$ і висотою $h_{z p}=\frac{B_{c}}{2} \sin \gamma$, яка дорівнює відстані між основами в напрямі нормалі.

Об’єм зрізаної піраміди можливо визначати за залежністю [8]

$$
V_{z p}=h_{z p}\left(S_{1}+\sqrt{S_{1} S_{2}}+S_{2}\right) / 3
$$

де $S_{1}, S_{2}$ - відповідно площі основ $E_{c}^{\prime} E^{\prime} D^{\prime} D_{c}^{\prime}$ і $E_{c} E D D_{c}$.

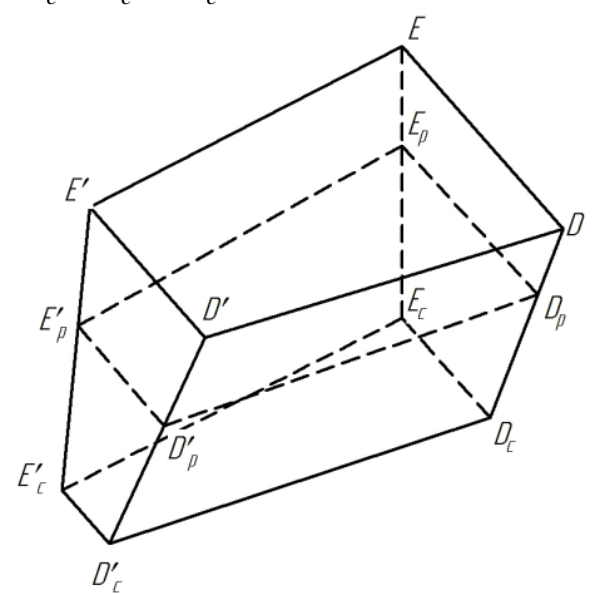

Рис.4 - Верхня частина піскового тіла механічного спірального класифікатора при повному заповненні простору між витками

Основи зрізаної піраміди в процесі експлуатації створюються робочими елементами спіралі, тому їх висота буде однаковою і визначиться залежністю

$$
h_{o p}=\frac{h-h_{c}}{\cos \alpha},
$$

де $h$ - змінний рівень пісків у міжвитковому просторі спіралі у напрямі вертикалі.

Першу основу можливо вважати трикутником, тому іiі площа визначиться залежністю 


$$
S_{1}=D_{p}^{\prime} E_{p}^{\prime} \cdot h_{o p} / 2
$$

де $D_{p}^{\prime} E_{p}^{\prime}$ - поточне значення змінної основи трапеції площею $S_{l}$.

Площа другої основи дорівнює

$$
S_{2}=h_{o p}\left(D_{p} E_{p}+D_{c} E_{c}\right) / 2 \text {, }
$$

де $D_{p} E_{p}$ - поточне значення змінної основи трапеції площею $S_{2}$.

Для визначення площі основ зрізаної піраміди необхідно знайти їх сторони $D_{p}^{\prime} E_{p}^{\prime}, D_{p} E_{p}$ i $D_{c} E_{c}$. Для цього розглянемо піскове тіло механічного спірального класифікатора у площині, нормальній до осі обертання спіралі, біля заднього витка (рис.5) і визначимо довжини хорд, що відповідають певним рівням матеріалу. 3 прямокутного трикутника, однією з сторін якого є половина хорди, що відповідає горизонтальній площині нижньої частини піскового тіла, знаходимо

звідки

$$
F_{c} E_{c} / 2=\sqrt{R_{c}^{2}-\left(R_{c}-h_{c}\right)^{2}}
$$

$$
D_{c} E_{c}=2 \sqrt{R_{c}^{2}-\left(R_{c}-h_{c}\right)^{2}} / \sin \gamma \text {. }
$$

3 залежності (15) видно, що $D_{c} E_{c} \epsilon$ константою для конкретного класифікатора.

3 прямокутного трикутника, однією з сторін якого (рис.5) є половина хорди, що відповідає поточній горизонтальній площині верхньої частини піскового тіла, знаходимо

$$
F_{p} E_{p} / 2=\sqrt{R_{c}^{2}-\left(R_{c}-h\right)^{2}},
$$

звідки

$$
F_{p} E_{p}=2 \sqrt{R_{c}^{2}-\left(R_{c}-h\right)^{2}}
$$

де $h$ - поточна висота пісків у міжвитковому просторі класифікатора, яка змінюється в межах $h_{c}<h<h_{\text {max }}$.

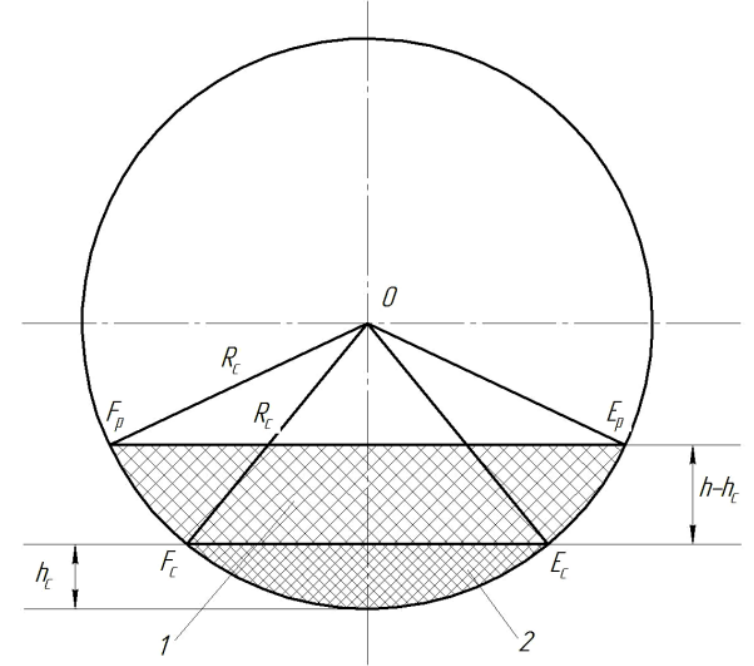

1, 2 - відповідно верхня і нижня частини піскового тіла

Рис.5 - Положення хорд кола, що відповідає діаметру спіралі класифікатора при зміні рівня пісків класифікатора

Відповідно (17) запишемо

$$
D_{p} E_{p}=2 \sqrt{R_{c}^{2}-\left(R_{c}-h\right)^{2}} / \sin \gamma
$$


Висота $h_{c}$ відповідає нульовій відмітці верхньої частини піскового тіла (рис.4), де можливо рахувати, що довжина хорди $D_{c}^{\prime} E_{c}^{\prime}=0.3$ ростом рівня пісків $h$ у міжвитковому просторі відносно горизонтальної площини $D_{c}^{\prime} E_{c}^{\prime} E_{c} D_{c}$ він змінюється однаково біля переднього і заднього витка. Зміна рівня буде складати $h$ - $h_{c}$, де $h$, зростаючи від 0 буде перевищувати $h_{c}$. Тоді, аналогічно рис.5, з врахуванням рис.4 з прямокутного трикутника визначимо

$$
F_{p}^{\prime} E_{p}^{\prime} / 2=\sqrt{R_{c}^{2}-\left[R_{c}-\left(h-h_{c}\right)\right]^{2}}
$$

3 врахуванням (19) аналогічно (15) і (18) запишемо

$$
D_{p}^{\prime} E_{p}^{\prime}=2 \sqrt{R_{c}^{2}-\left[R_{c}-\left(h-h_{c}\right)\right]^{2}} / \sin \gamma,
$$

де $h$ змінюється від 0, але більше $h_{c}$.

3 врахуванням отриманих параметрів об’єм верхньої частини піскового тіла механічного спірального класифікатора буде дорівнювати

$$
V_{z p}=\frac{B_{c}\left(h-h_{c}\right)}{6 \cdot \cos \alpha}[A+B+C+\sqrt{(B+C) A}]
$$

де $A=\sqrt{R_{c}^{2}-\left[R_{c}-\left(h-h_{c}\right)\right]^{2}}$;

$B=\sqrt{R_{c}^{2}-\left(R_{c}-h\right)^{2}}$;

$C=\sqrt{R_{c}^{2}-\left(R_{c}-h_{c}\right)^{2}}=$ const.

Об'єм піскового тіла класифікатора буде дорівнювати

$$
V_{p T}=V_{B C}+V_{z p}
$$

Як видно з залежностей (9) і (21), об’єм піскового тіла класифікатора однозначно визначається рівнем матеріалу у міжвитковому просторі спіралі. Ця залежність $є$ достатньо складною. При малих значеннях рівня $h$ в межах $0 . . h_{c}$ об'єм піскового тіла характеризується доданком $V_{B C}(9)$. Якщо рівень $h>h_{c}$, то об'єм піскового тіла включає незмінну частину $V_{B C}$, збільшену на доданок $V_{z p}$ при певному рівні пісків $h>h_{c}$.

Визначимо отримані залежності за умов конкретного технологічного агрегату. Розглянемо механічний спіральний класифікатор типу $1 \mathrm{KCH}-30$, який встановлюють під кутом $\alpha=18^{\circ} 30^{\prime}$ до горизонту. Він має двозахідну спіраль діаметром $3 \mathrm{M}\left(R_{c}=1,5 \mathrm{M}\right)$, крок $B_{c}=1,8 \mathrm{M}$, робочі елементи висотою $h_{e}=330 \mathrm{Mм}$.

Враховуючи технічні характеристики даного класифікатора, подамо рівняння (9) і (21) у конкретизованому виді, де лінійні розміри приведемо у метрах

$$
V_{B C}=10,087\left(\sin \beta-\frac{\sin ^{3} \beta}{3}-\beta_{p} \cos \beta\right), \mathrm{M}^{3}
$$

де $\beta=\arccos (1-h / 1,5 \cdot \cos \alpha)$,

$$
\begin{array}{r}
V_{z p}=0,3113(h-0,2405)[A+B+C+\sqrt{(B+C) A}], \\
\text { де } A, B \text { і } C \text { відповідно дорівнюють } \sqrt{2,25-(1,7405-h)^{2}}, \sqrt{2,25-(1,5-h)^{2}} \text { і } 0,8147 \text { м. }
\end{array}
$$

В залежності (23) $h$ змінюється в межах $0 \ldots h_{c}$ або $0 \ldots 0,2405$ м, а в (24) рівень пісків $h$ знаходиться в межах $h_{c}<h<h_{\max }$, тобто, $з$ врахуванням (3) рівень пісків змінюється від 0,2405 до 0,3565 м.

В процесі комп'ютерного моделювання за (23) і (24) отримані залежності, які приведені на рис.6. Залежність 1 для верхнього піскового тіла практично лінійна. Залежність об'єму піскового тіла механічного спірального класифікатора від рівня пісків у міжвитковому просторі у відповідності з графіком 2 в межах нижньої частини піскового тіла нелінійна. Нелінійна ділянка залежності відноситься до діапазону зміни рівня $0 \ldots 15$ см, який відповідає малим значенням циркулюючого навантаження, які на практиці не використовуються. Тому в межах нижньої частини піскового тіла також існує практично лінійна залежність рівня пісків від їх об’єму. Графік 3 відповідає рівнянню (22). Тому графіки 2 і 3 характеризують залежність на всьому діапазоні зміни продуктивності класифікатора по піскам. Вона наближено лінійна. 


\section{МЕТОДИ ТА АЛГОРИТМИ ЕФЕКТИВНОГО УПРАВЛІННЯ ОБ‘ЭКТАМИ}

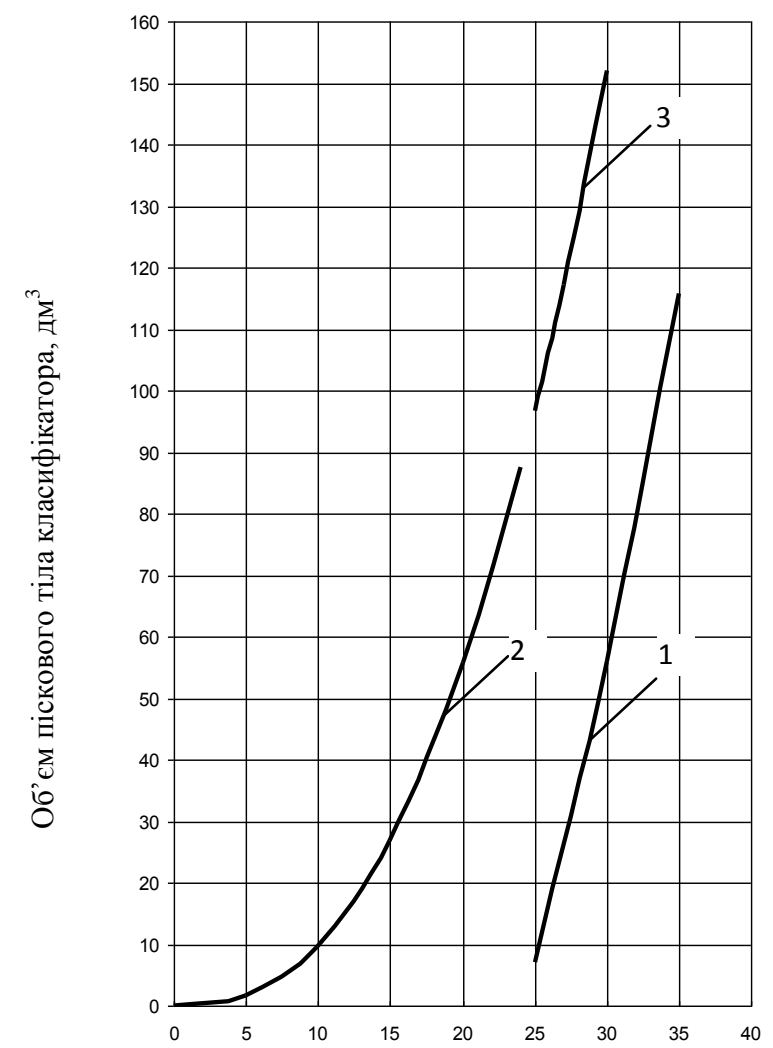

Рівень пісків у міжвитковому просторі спірального класифікатора, см

$$
1-25 \ldots 35 \mathrm{~cm} ; 2-0 \ldots 24 \mathrm{~cm} ; 3-0 \ldots 30 \mathrm{~cm}
$$

Рис.6 - Залежність об’єму піскового тіла механічного спірального класифікатора від рівня пісків у міжвитковому просторі в діапазоні

В процесі математичного моделювання застосовувались точні аналітичні методи дослідження, що гарантують об'єктивність отриманих результатів. Зроблені допущення щодо подання верхньої частини піскового тіла класифікатора у вигляді зрізаної піраміди не спотворюють процес його формування, оскільки, як видно 3 графіків 2 і 3 (рис.6), точки, отримані відповідно точному геометричному тілу - відрізку циліндра, знаходяться на загальній залежності, що відповідає і геометричному тілу зі зробленими допущеннями. Тому ствердно відмічаємо, що об’єм піскового тіла механічного спірального класифікатора у міжвитковому просторі спіралі можливо визначати за рівнем твердого вздовж вертикалі, яка проходить через точку контакту постелі і заднього витка у самій нижній точці.

\section{Висновки}

Таким чином, в процесі математичного моделювання формування піскового тіла механічного спірального класифікатора отримана аналітична залежність об'єму твердого у міжвитковому просторі від його рівня вздовж вертикалі, що проходить через точку контакту постелі і заднього витка у самій нижній точці. На основі аналізу отриманої залежності зроблено висновок про можливість прямого вимірювання продуктивності механічного спірального класифікатора по піскам. Даний підхід позбавлений вад, які притаманні попереднім розробкам цього призначення.

Виконані дослідження відкривають перспективу розробки засобу вимірювання продуктивності механічного спірального класифікатора по пісках, який позбавлений запізнювання і забезпечує високу точність вимірювання технологічного параметра. Це дозволить ефективно керувати процесом розділення подрібненого матеріалу на дрібний і крупний класи. 
Література

[1] А.c. 329905 СССР, МКИ В03С 5/00. Способ непрерывного измерения циркулирующей нагрузки / Т.И. Гуленко, В.А. Кондратец (СССР) -№1352391/29-33; заявл. 28.07.69; опубл. 24.02.72, Бюл. №8;

[2] А.с. 1269838 СССР, МКИ В03В 13/00. Способ определения производительности спирального классификатора по пескам / В.И. Дмитриев (СССР) - №3904014/22-03; заявл. 27.05.85; опубл. 15.11.86, Бюл. №42;

[3] А.с. 1530258 СССР, МКИ В03В 13/00. Способ определения производительности спирального классификатора по пескам / Е.Ф. Морозов (СССР) - №4385577/22-03; заявл. 29.02.88; опубл. 23.12.89, Бюл. №47;

[4] А.с. 1659102 СССР, МКИ В03В 13/00. Способ оперативного определения производительности спирального классификатора по пескам / В.И. Дмитриев (СССР) - №4645509/03; заявл. 19.12.88; опубл. 30.06.91, Бюл. № 24;

[5] А.с. 619209 СССР, МКИ В03В 13/00. Способ автоматического контроля производительности спиральных классификаторов по пескам / А.Н. Марюта, Е.В. Кочура, В.И. Дмитриев (СССР) №2344570/22-03; заявл. 17.03.76; опубл. 15.08.78, Бюл. № 30;

[6] Дмитриев В.И. Исследования динамических характеристик спирали классификатора для задач автоматического контроля / В.И. Дмитриев // Зб. наук. праць Національного гірничого університету.Дніпропетровськ: Державний вищий навчальний заклад «Національний гірничий університет», 2007.№28.- С.14-24;

[7] Бронштейн И.Н. Справочник по математике для инженеров и учащихся вузов / И.Н. Бронштейн, К.А. Семендяев.- М.: Гос. изд. физико-математической литературы, 1959.- 608 с;

[8] Корн Г. Справочник по математике для научных работников и инженеров (определения, теоремы, формулы) / Г. Корн, Т. Корн.- М.: Наука, 1973.- 832 с.

\section{References}

[1] A.s. 329905 SSSR, MKI V03S 5/00. Sposob nepreryvnogo izmereniya tsirkuliruyushchei nagruzki / T.I. Gulenko, V.A. Kondratets (SSSR) -№1352391/29-33; zayavl. 28.07.69; opubl. 24.02.72, Byul. №8;

[2] A.s. 1269838 SSSR, MKI V03V 13/00. Sposob opredeleniya proizvoditel'nosti spiral'nogo klassifikatora po peskam / V.I. Dmitriev (SSSR) - №3904014/22-03; zayavl. 27.05.85; opubl. 15.11.86, Byul. №42;

[3] A.s. 1530258 SSSR, MKI V03V 13/00. Sposob opredeleniya proizvoditel'nosti spiral'nogo klassifikatora po peskam / E.F. Morozov (SSSR) - №4385577/22-03; zayavl. 29.02.88; opubl. 23.12.89, Byul. №47;

[4] A.s. 1659102 SSSR, MKI V03V 13/00. Sposob operativnogo opredeleniya proizvoditel'nosti spiral'nogo klassifikatora po peskam / V.I. Dmitriev (SSSR) - №4645509/03; zayavl. 19.12.88; opubl. 30.06.91, Byul. № 24 ;

[5] A.s. 619209 SSSR, MKI V03V 13/00. Sposob avtomaticheskogo kontrolya proizvoditel'nosti spiral'nykh klassifikatorov po peskam / A.N. Maryuta, E.V. Kochura, V.I. Dmitriev (SSSR) - №2344570/22-03; zayavl. 17.03.76; opubl. 15.08.78, Byul. № 30;

[6] Dmitriev V.I. Issledovaniya dinamicheskikh kharakteristik spirali klassifikatora dlya zadach avtomaticheskogo kontrolya / V.I. Dmitriev // Zb. nauk. prac' Nacional'nogo girnychogo universytetu.Dnipropetrovs'k: Derzhavnyj vyshhyj navchal'nyj zaklad «Nacional'nyj girnychyj universytet», 2007.- №28.S.14-24;

[7] Bronshtein I.N. Spravochnik po matematike dlya inzhenerov i uchashchikhsya vuzov / I.N. Bronshtein, K.A. Semendyaev.- M.: Gos. izd. fiziko-matematicheskoi literatury, 1959.- 608 s;

[8] Korn G. Spravochnik po matematike dlya nauchnykh rabotnikov i inzhenerov (opredeleniya, teoremy, formuly) / G. Korn, T. Korn.- M.: Nauka, 1973.- 832 s. 